\title{
Studies on the nutrition of marine flatfish. The metabolism of glucose by plaice (Pleuronectes platessa) and the effect of dietary energy source on protein utilization in plaice
}

\author{
By C. B. COWEY, J. W. ADRON AND D. A. BROWN \\ Institute of Marine Biochemistry, St Fittick's Road, Aberdeen $A B$ I ${ }_{3} R A$ \\ AND AILEEN M. SHANKS \\ Marine Laboratory, Victoria Road, Aberdeen $A B 98 D B$
}

(Received 8 fuly I974-Accepted I4 August I974)

\begin{abstract}
I. The effects of dietary energy level and dietary energy source on protein utilization by plaice (Pleuronectes platessa) were examined by giving diets containing $400 \mathrm{~g}$ crude protein/ $\mathrm{kg}$ to nine groups of fish. Five of these diets contained only lipid as a source of energy (in addition to protein) and their energy contents were varied by increasing the lipid level in a stepwise manner from 56 to $176 \mathrm{~g} / \mathrm{kg}$. The remaining four diets contained both lipid and carbohydrate (glucose + dextrin) together as energy sources: two levels of carbohydrate (roo and
\end{abstract} $200 \mathrm{~g} / \mathrm{kg}$ ) being used at each of two $(56$ and $86 \mathrm{~g} / \mathrm{kg})$ lipid levels.

2. Weight gains of plaice given the diets containing only lipid as an energy source did not differ significantly from each other. Weight gains of plaice given diets containing carbohydrate as well as protein and lipid were superior to those given diets lacking carbohydrate.

3. Values obtained for protein efficiency ratio (PER) and net protein utilization (NPU) increased with increasing dietary energy level in both those fish given the diets containing carbohydrate and those given diets lacking it. Both PER and NPU values were greater for plaice given diets containing carbohydrate than for fish diets without carbohydrate even when the total energy content of the diets was approximately the same.

4. Liver glycogen levels were significantly higher in plaice given diets containing $200 \mathrm{~g}$ carbohydrate $/ \mathrm{kg}$ than in plaice given diets without carbohydrate. Blood glucose levels and hepatic hexokinase $(E C 2.7,1.1)$ levels were not significantly different in plaice given these diets. No glucokinase $(E C$ 2.7. I .2) was detected in plaice given either diet.

5. The metabolic fate of glucose carbon in plaice was investigated by injecting the fish intraperitoneally with $\left[\mathrm{U}^{14} \mathrm{C}\right] \mathrm{glucose}$ and examining, $\mathrm{I} 8 \mathrm{~h}$ afterwards, the distribution of radioactivity in different biochemical fractions from the fish.

6. Glucose was respired much less rapidly in the carnivorous plaice, irrespective of dietary treatment, than in omnivorous mammals (mouse and rat). The rate of production of ${ }^{14} \mathrm{CO}_{2}$ from $\left[\mathrm{U}^{14} \mathrm{C}\right]$ glucose by plaice given diets containing carbohydrate was not significantly greater than that by plaice given diets lacking carbohydrate.

7. More glucose was incorporated into liver glycogen when plaice were given carbohydrate in their food than when it was absent. Otherwise no differences were apparent in the fate of glucose $\mathbf{C}$ by plaice which could be related to the diets used.

8. No mortalities occurred nor was any histopathology observed in the plaice as a consequence of the inclusion of carbohydrate in the food.

The utilization of dietary protein is affected by a number of factors: these include the total energy intake and the protein energy: total energy ratio. In those birds and mammals which have been investigated the major energy-supplying materials (fat and carbohydrate) exert more or less equivalent sparing effects on the utilization of protein (Swanson, 1959). The sparing action of these materials in fish diets is complicated, however, partly by environmental factors and partly by the metabolic 
characteristics of the fish. Results from different laboratories suggest that differences may occur between species and in particular there is some disagreement over the effect of dietary carbohydrate on the health of the fish.

Dupree (1969), using channel catfish (Ictalurus punctatus), a non-fatty fish, found that an increase in dietary fat level from 40 to $80 \mathrm{~g} / \mathrm{kg}$ diet led to sparing of protein, but a further increase to $160 \mathrm{~g} / \mathrm{kg}$ did not increase the sparing effect. Similarly greater sparing of dietary protein occurred when diets contained $80 \mathrm{~g}$ dextrin $/ \mathrm{kg}$ than when they contained $160 \mathrm{~g} / \mathrm{kg}$, and the best weight gains were obtained when fat and carbohydrate were present in approximately equal quantities. By contrast Lee \& Putnam (1973) using rainbow trout (Salmo gairdnerii), a relatively fatty fish, in a factorial type experiment obtained the best protein efficiency ratio (PER) with a diet containing $240 \mathrm{~g}$ fat $/ \mathrm{kg}$ and a similar quantity of carbohydrate.

Phillips (I 969) claimed that trout given quite low levels of raw starch developed high blood sugar levels and accumulated large amounts of glycogen in the liver, but these claims are at variance with the findings of Buhler \& Halver (I96r) on Chinook salmon (Oncorhynchus tschawytsha).

As these different responses may be related to the metabolic characteristics of the species of fish used, the metabolism of glucose in plaice, a non-fatty marine fish with an adipose liver (Cowey \& Sargent, I972), has been examined by following the fate of glucose carbon after intraperitoneal injection of $\left[\mathrm{U}-{ }^{14} \mathrm{C}\right]$ glucose into plaice. Also the effects of energy source and total energy level at constant dietary protein level on growth rate, food conversion and body composition of plaice have been investigated.

In the natural environment plaice are carnivorous and feed on different prey (Tellina siphons, Arenicola) as they increase in size (Edwards, Finlayson \& Steele, 1969; Braber \& De Groot, 1973). This natural food is predominantly protein with a composition in the range ( $\mathrm{g} / \mathrm{kg}$ dry weight): protein $75^{\circ-800}$, carbohydrate $70-90$, lipid 70-1 Io and ash 70-1 Io (Edwards et al. 1969).

The results show that glucose carbon is oxidized to $\mathrm{CO}_{2}$ much less rapidly in plaice than in omnivorous simple-stomached mammals and that rather less glucose $\mathrm{C}$ is incorporated into lipid than is the situation in such mammals. Otherwise the distribution of glucose $\mathrm{C}$ among tissue components does not appear greatly different in the two animals. Despite this, measurements of weight gain and food conversion indicate that diets containing both a readily assimilable carbohydrate and fat together with sources of energy are superior in terms of net protein utilization (NPU) or PER to diets from which carbohydrate is totally excluded.

\section{EXPERIMENTAL}

\section{Diets}

The composition of the diets used is shown in Table $\mathrm{I}$ : white fish meal was used as a protein source, the lipid was a mixture of equal weights of maize oil and cod-liver oil together with lipid present in the fish meal, and the carbohydrate was a mixture of equal weights of glucose and dextrin. Vitamin and mineral mixtures and the binding agent were identical with those used earlier (Cowey, Pope, Adron \& Blair, I972). In 
Table I. Composition ( $g / k g$ dry diet) of the experimental diets given to plaice

\begin{tabular}{|c|c|c|c|c|c|c|c|c|c|}
\hline \multirow[b]{2}{*}{ Component } & \multicolumn{9}{|c|}{ Diet } \\
\hline & I & 2 & 3 & 4 & 5 & 6 & 7 & 8 & 9 \\
\hline White fish meal & 570 & 570 & 570 & 570 & 570 & 570 & 570 & 570 & 570 \\
\hline Cod-liver oil & 30 & 30 & 45 & 60 & 75 & 30 & 30 & 30 & 30 \\
\hline Maize oil & 0 & 30 & 45 & 60 & 75 & 0 & 0 & 30 & 30 \\
\hline Dextrin & $\circ$ & 0 & 0 & $\circ$ & 0 & 50 & 100 & 50 & 100 \\
\hline Glucose & $\circ$ & o & o & $\circ$ & $\circ$ & 50 & 100 & 50 & 100 \\
\hline$\alpha$-Cellulose & 319 & 289 & 259 & 229 & 199 & 219 & 119 & 189 & 89 \\
\hline Vitamin premix* & 28 & 28 & 28 & 28 & 28 & 28 & 28 & 28 & 28 \\
\hline Mineral mixture* & 3 & 3 & 3 & 3 & 3 & 3 & 3 & 3 & 3 \\
\hline Binder $\nmid$ & 50 & 50 & 50 & 50 & 50 & 50 & 50 & 50 & 50 \\
\hline Crude protein (g) & 400 & 400 & 400 & 400 & 400 & 400 & 400 & 400 & 400 \\
\hline Total lipid $f(\mathrm{~g})$ & 56 & 86 & II 6 & 146 & 176 & 56 & 56 & 86 & 86 \\
\hline $\begin{array}{l}\text { Digestible carbo- } \\
\text { hydrate }(\mathrm{g})\end{array}$ & 0 & $\circ$ & $\circ$ & 0 & 0 & 100 & 200 & 100 & 200 \\
\hline \multicolumn{10}{|c|}{ Estimated total energy value:§ } \\
\hline MJ & $7 \cdot 95$ & 10.92 & $12 \cdot 13$ & 13.32 & $14.5 \mathrm{I}$ & II $* 42$ & 13.09 & $12 \cdot 61$ & $14 \cdot 28$ \\
\hline kcal & 2332 & 2617 & 2902 & 3187 & 3472 & 2732 & 3132 & 3017 & 3417 \\
\hline \\
\hline total energy & 0.77 & 0.69 & 0.62 & 0.56 & 0.52 & 0.66 & 0.57 & 0.60 & 0.53 \\
\hline
\end{tabular}

addition to the diets shown in Table I, a low-protein diet (Cowey et al. 1972) was given to a further group of fish so that measurements of NPU could be made as described by Cowey et al. (1972). Values for growth obtained with this diet were not included in the analysis of weight gains. Diets were stored at $-15^{\circ}$ until used.

It was pointed out previously (Cowey et al. 1972) that the energy value usually quoted for protein $\left(16.74 \mathrm{~kJ}\left(4^{\circ} \circ \mathrm{kcal}\right) / \mathrm{g}\right)$ is not necessarily valid for fish, partly because they excrete the bulk of their non-faecal waste nitrogen as ammonia through the gills. Since that paper was written Smith (1971) has published the results of his studies on the metabolizable energy of fish foods. He obtained a value for the metabolizable energy of protein $(18.83 \mathrm{~kJ}(4.5 \mathrm{kcal}) / \mathrm{g})$ higher than that generally accepted for mammals. In the absence of other experimental results, Smith's value has been used in estimating the energy content of the diets used in the present experiment.

The diets were given to the fish as moist pellets (water content $35^{\circ} \mathrm{g} / \mathrm{kg}$ ); these were made in an Alexanderwerk pelleting machine (Orthos (Engineering) Ltd, Market Harborough, Leicestershire).

\section{Animals}

Plaice (Pleuronectes platessa), about 9 months old, were obtained from the White Fish Authority Marine Fish Cultivation Unit, Hunterston, Ayrshire, where they had been fed on a diet of minced, trash fish. The plaice were distributed between ten tanks $(\mathrm{r} \cdot 9 \times 0.84 \times 0.6 \mathrm{r} \mathrm{m})$ in the Institute aquarium which has been described fully by Cowey, Adron, Blair \& Shanks (1974). Fish were first weaned onto an artificial diet (diet I, Table $\mathrm{I}$ ). Some fish were then discarded from each tank and a small 
number of others re-allocated between the ten tanks in such a way as to provide, in each tank, approximately equal numbers of individuals, a similar total biomass and a similar size distribution. The fish in each tank were then marked by subdermal injection of differently coloured latex dyes on the ventral surface so that they were individually identifiable.

After ${ }^{2-3}$ weeks on this diet, fish were given the nine experimental diets (Table $\mathrm{I}$ ) for $3 \mathrm{~d}$; all the fish in the same tank received the same diet. The Ioth group of fish were given the low-protein diet mentioned earlier. All the diets were readily accepted by the fish, therefore initial weight measurements were made (Cowey et al. 1974). Analysis of variance of these initial weights of fish between tanks and within tanks showed no significant differences.

Fish were fed to satiation 3 times/d (08.30, 12.00 and 16.30 hours). For each treatment a quantity of moist pellets was weighed daily and a limited number of them ( $15-20)$ were dropped into the appropriate tank. These were normally consumed rapidly and a further limited number of pellets were added to the tank. These were again eaten quickly and the procedure was repeated; numbers of pellets were decreased each time. When the fish ceased to react to pellets entering the water, feeding was stopped. With experience it became possible to feed the fish to satiation with no wastage of food - that is, with not more than two pellets remaining uneaten on the bottom of the tank. Feeding was carried out by one member of the aquarium staff alone. The fish were weighed at bi-weekly intervals and the experiment lasted 8 weeks.

With the resources available it was not possible to replicate the tanks allotted to each diet. Experience with this tank system has shown, however, that groups of fish of a similar size kept in separate tanks and given the same diet do not differ in growth rate. Moreover, at each bi-weekly weighing, fish were returned to a different experimental tank from that in which they spent the previous fortnight.

At the start of the experiment there were twenty-eight or twenty-nine fish in each tank. No mortalities occurred during the experiment. A small number of fish given some of the diets showed abnormally large or small growth, and values for them were excluded from the analysis of weight gains, but were included in the measurement of PER and NPU. Table 3 gives the number of fish used in the analysis of growth and the mean initial weight of these fish for each diet.

Values for liver glycogen, blood sugar and liver hexokinase (EC 2.7 . I I I) were estimated using larger plaice (70-90 g) which had been kept in two additional separate tanks and given either diet $\mathrm{I}$ or diet 9 for 6 weeks. The experiments on glucose metabolism described below were also done using these fish.

\section{Chemical methods}

At the end of the experiment all the fish from each treatment were grouped together as a single sample. They were all killed by a sharp blow on the head, dried to constant weight in a vacuum oven $\left(4^{\circ}\right)$ and ground to a homogeneous powder, first using a pestle and mortar and then using a hammer mill. Replicate analyses of these powders for protein, ash and lipid contents were done using methods described by Cowey et al. (1972). 
Liver glycogen was isolated as described by Lee $\&$ Whelan (1966). It was hydrolysed in $0.75 \mathrm{M}$-sulphuric acid for $3 \mathrm{~h}$ at $100^{\circ}$ and the glucose in the neutralized solution was determined by a glucose-oxidase method (Krebs, Bennett, De Gasquet, Gascoyne \& Yoshida, 1963).

Blood sugar measurements were done using blood taken from the caudal vein; this was deproteinized with an equal volume of $0.6 \mathrm{M}$-perchloric acid and the glucose content estimated using the glucose-oxidase method.

For measurement of hexokinase activity, plaice livers were homogenized in $5 \mathrm{vol}$. of an ice-cold solution containing $150 \mathrm{mM}-\mathrm{KCl}, 4 \mathrm{mM}-\mathrm{MgSO}_{4}, 4 \mathrm{~mm}-\mathrm{EDTA}$, and $4 \mathrm{mM}-\mathrm{N}$-acetyl cysteine, $\mathrm{pH} 7 \cdot 0$. The homogenate was centrifuged at $20000 \mathrm{~g}$ for $30 \mathrm{~min}$ and the supernatant fraction assayed for hexokinase activity. The hexokinase assay was done spectrophotometrically at $15^{\circ}$ using a Unicam SP 800 recording spectrophotometer (Pye Unicam Ltd, Cambridge) equipped with a constanttemperature cell housing. The cuvette contained, in a final volume of $3.0 \mathrm{ml}: 50 \mathrm{~mm}-$

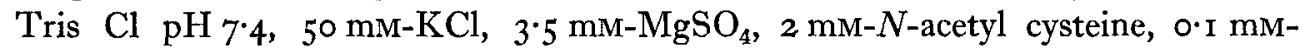
NADP, 2 mM-ATP, $0 \cdot 5$ or 50 mM-glucose, $2.5 \mu \mathrm{g}$ glucose- 6 -phosphate dehydrogenase (EC I.I.I.49) and ro $\mu$ g 6-phosphogluconic dehydrogenase (EC I.I.I.43). The reaction was started by addition of the extract.

Liver glycogen, blood sugar and liver hexokinase activity estimations were done 2-3 $\mathrm{h}$ after feeding. Each of these components was estimated for six individuals from each treatment (diet $I$ and diet 9).

\section{Experiments on glucose metabolism}

Plaice $(70-90 \mathrm{~g})$ which had been given either diet I or diet 9 for 6 weeks were injected intraperitoneally with $5 \mu \mathrm{Ci}$ [U- ${ }^{14} \mathrm{C}$ ]glucose in $0.2 \mathrm{ml}$ of a solution containing $2 \mathrm{mg}$ carrier glucose $/ \mathrm{ml}$. The fish, from which food had been withheld for $\mathrm{I} 8 \mathrm{~h}$ before the injection, was then immediately placed separately in 41 filtered sea water, containing $200 \mathrm{mg}$ sodium benzyl penicillin and $200 \mathrm{mg}$ streptomycin sulphate, in a desiccator. The sea water was buffered at $\mathrm{pH} 8.0$ with Io $\mathrm{g}$ fish grade Trizma (Sigma Chemical Co. Ltd, London).

Three gas-absorption bottles (each containing $25 \mathrm{ml} \mathrm{I} \mathrm{M}-\mathrm{NaOH}$ ) were attached in series to the desiccator, and air, free of $\mathrm{CO}_{2}$, was drawn constantly through the sea water and through the gas-absorption bottles in which the expired $\mathrm{CO}_{2}$ was trapped. Suction through the system was stopped $18 \mathrm{~h}$ after the injection, and the fish was rapidly removed from the desiccator and killed by a sharp blow on the head. The sea water in the desiccator was acidified to $\mathrm{pH} 2$ with $6 \mathrm{M}-\mathrm{HCl}$ immediately after removal of the fish and the air stream through the sea water and the $\mathrm{CO}_{2}$ traps resumed for a further $60 \mathrm{~min}$. Thus all the $\mathrm{CO}_{2}$ in the sea water, including that expired by the fish, was collected in the traps.

The fish were processed according to scheme 2 of Vrba (1966) except that they were not frozen in liquid nitrogen but were immediately cut into small pieces and homogenized in $0.5 \mathrm{M}$-perchloric acid.

Radioactivity in the fractions was measured by adding $0.1 \mathrm{ml}$ sample to $10 \mathrm{ml}$ scintillation fluid (Instagel; Packard Instrument Co. Inc., Illinois, USA) in a scintillation 
Table 2. Initial weights $(g)$ and average growth $(g)$ after 8 weeks, of plaice given diets containing different amounts and sources of energy

$\begin{array}{ccccc}\begin{array}{c}\text { Diet } \\ \text { no.* }\end{array} & \begin{array}{c}\text { No. of } \\ \text { fish }\end{array} & \begin{array}{c}\text { Mean } \\ \text { initial } \\ \text { wt }\end{array} & \text { Mean } & \text { SE } \\ 1 & 25 & 17.16 & 6.51 & 0.768 \\ 2 & 28 & 17.09 & 6.83 & 0.656 \\ 3 & 28 & 16.16 & 7.29 & 0.698 \\ 4 & 27 & 16.87 & 6.64 & 0.602 \\ 5 & 28 & 17.01 & 7.56 & 0.728 \\ 6 & 28 & 16.58 & 8.55 & 0.796 \\ 7 & 22 & 15.83 & 8.59 & 0.720 \\ 8 & 29 & 16.49 & 8.51 & 0.846 \\ 9 & 25 & \text { I6.56 } & 10.79 & 0.979 \\ & & \text { * For details, see Table I. } & \end{array}$

vial. Samples were counted using a liquid scintillation spectrometer (Tricarb model 3385 ; Packard Instrument $\mathrm{Co}$. Inc.). The efficiency of counting was $75 \%$ and samples were counted to give an accuracy of $\pm 1 \%$ standard deviation.

Experiments were done using three fish from each dietary treatment.

\section{RESULTS}

Growth, protein utilization and body composition

The growth, in terms of weight, of the animals given the nine diets was compared by first obtaining average growth curves for each diet. The growth of each fish could be represented by a quadratic curve. The curve was fitted to the five observations and was used to estimate the difference, $\Delta w$, between the initial and final weight. Mean values of $\Delta w$, and their standard errors, are given in Table 2.

For diets $I-5$ in which the only energy source (apart from protein) was lipid, there were no significant differences in average growth between treatments, nor was there any consistent trend between increasing lipid content of the diet and weight gain. Weight gains of fish given diets containing carbohydrate as well as lipid (diets 6-9) were all greater than those of fish given only lipid as an energy source, although only fish given diet 9 gained significantly more weight $(P<0.01)$ than all the groups given diets I-5. It may also be noted that at comparable dietary energy levels those diets which contained both carbohydrate and lipid as energy sources were superior to those which contained only lipid as an energy source (e.g. diet 9 compared with diet 5, diet 7 compared with diet 4).

The efficiency with which fish utilized protein in the experimental diets was examined by estimating PER and NPU. The results obtained are shown in Fig. $I$ and Table 3. The correlation coefficients between each of these measurements and the protein energy:total energy ratio are shown in Table 4. Both PER and NPU were negatively correlated with the protein energy: total energy ratio in the diet. The correlation coefficient between NPU and the protein energy: total energy ratio for diets 6-9, although not statistically significant, is nevertheless high. At any given total energy 


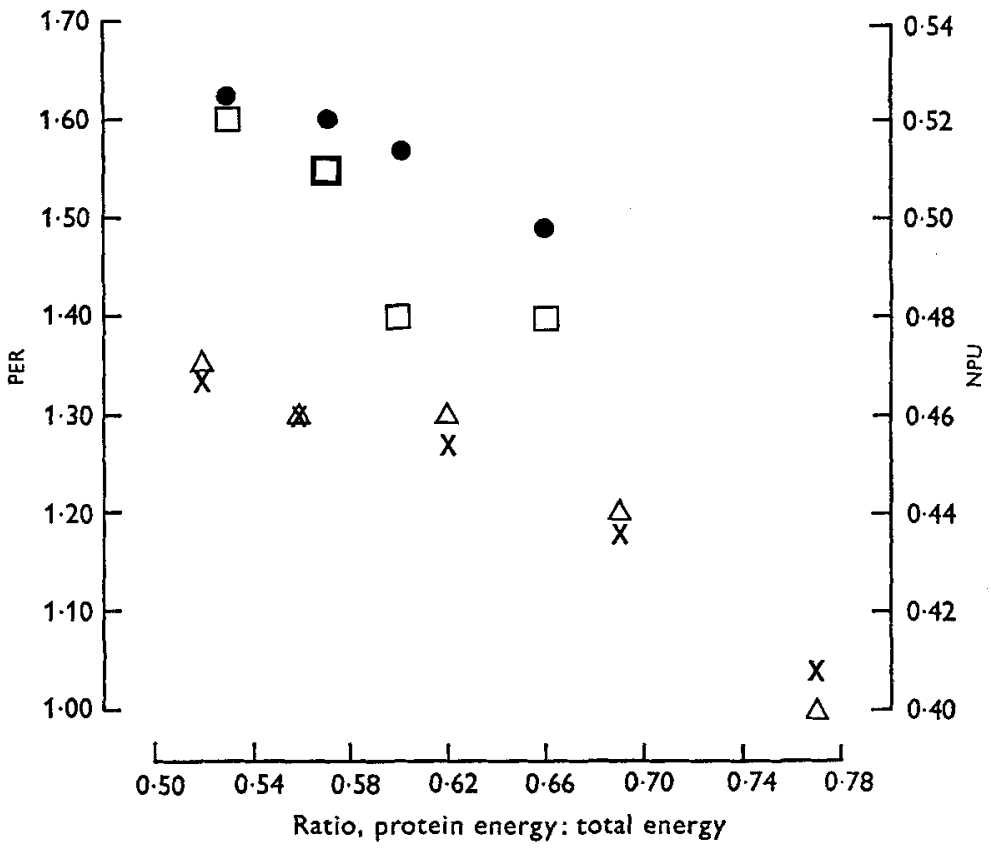

Fig. I. Relationship between protein efficiency ratio (PER) and net protein utilization (NPU) and protein energy : total energy ratio in plaice given diets containing different amounts and sources of energy. $\bullet$, PER for diets 6-9, containing carbohydrate and lipid: $\square$, NPU for diets 6-9, containing carbohydrate and lipid; $x$, PER for diets $I-5$, containing no carbohydrate; $\Delta$, NPU for diets $1-5$, containing no carbohydrate. For details of diets, see Table I.

Table 3. Total live-weight gains of plaice given diets containing different amounts and sources of energy, and biological measurements of protein utilization

\begin{tabular}{|c|c|c|c|c|c|c|c|c|}
\hline \multirow{3}{*}{$\begin{array}{l}\text { Diet } \\
\text { no.* }\end{array}$} & \multirow{3}{*}{$\begin{array}{l}\text { No. of } \\
\text { fish }\end{array}$} & \multicolumn{2}{|c|}{ Total weights } & \multirow{3}{*}{$\begin{array}{l}\text { Protein } \\
\text { consumed } \\
\text { (g) }\end{array}$} & \multirow{2}{*}{\multicolumn{2}{|c|}{ Energy consumed }} & \multirow[b]{3}{*}{ PER } & \multirow[b]{3}{*}{ NPU } \\
\hline & & \multirow{2}{*}{$\begin{array}{l}\text { Initial } \\
(\mathrm{g})\end{array}$} & \multirow{2}{*}{$\begin{array}{c}\text { Final } \\
\text { (g) }\end{array}$} & & & & & \\
\hline & & & & & $\mathrm{MJ}$ & kcal & & \\
\hline I & 28 & $479^{\circ} \mathrm{I}$ & $640 \cdot 7$ & I 55.4 & 379 & 906 & I. 04 & 0.40 \\
\hline 2 & 28 & $478 \cdot 5$ & $667 \cdot 9$ & I60.5 & $4 \cdot 38$ & $10_{50}$ & $x \cdot 18$ & 0.44 \\
\hline 3 & 29 & $468 \cdot 7$ & $676 \cdot 4$ & I63.5 & 4.95 & I 186 & $x \cdot 27$ & 0.46 \\
\hline 4 & 29 & $478 \cdot 6$ & $675 \cdot 4$ & $151 \cdot 3$ & 5.04 & I 206 & $x \cdot 30$ & 0.46 \\
\hline 5 & 28 & $476 \cdot 4$ & 688.7 & I $58 \cdot 4$ & $5 \cdot 75$ & 1375 & $\mathrm{I} \cdot 34$ & 0.47 \\
\hline 6 & 29 & $476 \cdot 5$ & $722 \cdot 9$ & I65.3 & 472 & I 129 & $x \cdot 49$ & 0.48 \\
\hline 7 & 29 & 470.5 & 710.5 & 149.7 & $4 \cdot 89$ & 1172 & $x \cdot 60$ & $0.5 I$ \\
\hline 8 & 29 & $478 \cdot 2$ & $725 \cdot 7$ & I 57.0 & 4.95 & I 184 & $x \cdot 57$ & 0.48 \\
\hline 9 & 28 & 467.9 & $75^{8} \cdot 7$ & 179.0 & $6 \cdot 39$ & 1529 & $I \cdot 62$ & 0.52 \\
\hline
\end{tabular}

PER, protein efficiency ratio (g wt gain/g protein eaten); NPU, net protein utilization $\left(\left(B-\left(B_{k}-I_{k}\right)\right) \div I\right.$, where $B$ and $B_{k}$ are the total body nitrogen, $I$ and $I_{k}$ are the $\mathrm{N}$ intakes of fish on the test and low-protein diets respectively).

* For details, see Table r. 
Table 4. Linear correlations between protein energy:total energy ratio and indices of protein utilization in plaice given diets containing different amounts and sources of energy

$\begin{array}{cccc}\begin{array}{c}\text { Dietary } \\ \text { groups* }\end{array} & \text { Index } & r & \begin{array}{c}\text { Statistical } \\ \text { significance : }\end{array} \\ \text { I-5 } & \text { PER } & -0.979 & < \\ \text { I-5 } & \text { NPU } & -0.942 & <0.01 \\ 6-9 & \text { PER } & -0.980 & <0.05 \\ 6-9 & \text { NPU } & -0.886 & \text { NS }\end{array}$

PER, protein efficiency ratio (g wt gain/g protein eaten); NPU, net protein utilization $\left(\left(B-\left(B_{k}-I_{k}\right)\right) \div I\right.$, where $B$ and $B_{k}$ are total body nitrogen, and $I$ and $I_{k}$ are $\mathrm{N}$ intakes of fish on test and low-protein diets respectively); NS, not significant $(P>0.05) ; r$, correlation coefficient.

* For details, see Table r.

level or protein energy:total energy ratio, higher values of both PER and NPU were obtained with diets containing carbohydrate than for those without it. Hence the diets were considered as two series for comparative purposes.

The slope of the regression line (Fig. I) relating PER to protein energy: total energy ratio for diets $\mathrm{I}-5$ was not significantly different from that for diets $6-9$. The intercepts of the two lines were, however, significantly different $(P<0.001)$. Fitted with a common slope, the equations of the two regression lines were:

$\mathrm{PER}=\mathrm{I} \cdot 9462-\mathrm{I} \cdot \mathrm{I} 396$ (protein energy: total energy ratio), for diets I-5;

$\mathrm{PER}=2 \cdot 2424-\mathrm{I} \cdot \mathbf{3} 396$ (protein energy:total energy ratio), for diets 6-9.

The relationship between NPU and protein energy: total energy ratio was similar to that between PER and this ratio. The equations of the regression lines for diets $1-5$ and diets 6-9 when fitted with a common slope were:

$\mathrm{NPU}=0.6199-0.275^{2}$ (protein energy: total energy ratio), for diets $\mathrm{I}-5$;

$\mathrm{NPU}=0.6599-0.275^{2}$ (protein energy: total energy ratio), for diets 6-9.

The intercepts of these lines differ significantly $(P<0.01)$.

Thus when plaice are given diets containing $400 \mathrm{~g}$ crude protein $/ \mathrm{kg}$ dry matter the provision of some of the energy as readily assimilable carbohydrate enhances protein utilization. In stating this it is recognized that the energy intakes of some of the groups of fish given diets 6-9, containing carbohydrate, tended to be higher than some of the groups of fish given diets $\mathbf{I}-5$, lacking carbohydrates (Tables I and 3 ). It is possible that the lower energy intakes of fish given diets $\mathbf{I}-5$, in so far as it occurred, may have contributed to the lower efficiency of protein utilization by these fish.

The body composition of the fish given the different diets is shown in Table 5. The most noteworthy point was the increase in body lipid with dietary lipid in fish given diets $\mathrm{x}-5$. Body lipid was positively correlated with dietary lipid $(r=+0.986$ for $3 \mathrm{df}$ ) in these fish and the regression equation relating the two variables was: body lipid $(\mathrm{g} / \mathrm{kg})=42 \cdot 6+0 \cdot 1047$ dietary lipid content $(\mathrm{g} / \mathrm{kg})$. 
Table 5. Gross composition ( $\mathrm{g} / \mathrm{kg}$ wet weight) at the end of the experiment of plaice given diets containing different amounts and sources of energy

\begin{tabular}{|c|c|c|c|c|c|c|}
\hline \multirow{2}{*}{$\begin{array}{l}\text { Diet } \\
\text { no.* }\end{array}$} & \multirow{2}{*}{$\begin{array}{l}\text { No. of } \\
\text { fish }\end{array}$} & \multicolumn{5}{|c|}{ Composition of plaice } \\
\hline & & Water & Protein & Lipid & Ash & Total \\
\hline I & 28 & $767 \cdot 4$ & 147.7 & $48 \cdot 4$ & $32 \cdot I$ & $995^{\circ} 6$ \\
\hline 2 & 28 & I. & 145.9 & $52 \cdot 2$ & 34.5 & 9897 \\
\hline 3 & 29 & $759^{\circ} \cdot 2$ & $\mathrm{I} 48 \cdot \mathrm{I}$ & 54.4 & $3 \mathrm{I} \cdot 8$ & 993.5 \\
\hline 4 & 29 & 763.3 & I $39 \cdot 2$ & $56 \cdot 6$ & $33 \cdot 6$ & $992^{\circ} 7$ \\
\hline 5 & 28 & $752 \cdot 1$ & 147.9 & $61 \cdot 9$ & $34 \cdot 2$ & $996 \cdot 2$ \\
\hline 6 & 29 & $771^{1} 7$ & 144.3 & $4 \pi \cdot 6$ & $3 I^{\prime} 5$ & $989 \cdot \mathrm{I}$ \\
\hline 7 & 29 & $771 \cdot 7$ & 147.5 & $42 \cdot 7$ & 30.8 & $992 \cdot 7$ \\
\hline 8 & 29 & $770 \cdot 3$ & $\mathrm{I} 4 \mathrm{r}^{\prime} \mathrm{O}$ & $50 \cdot 8$ & 33.8 & $995^{\circ} 9$ \\
\hline 9 & 28 & $738 \cdot 7$ & $154 \cdot 6$ & $6 \mathrm{I} \cdot \mathrm{I}$ & 33.7 & $988 \cdot I$ \\
\hline
\end{tabular}

\section{Fate of glucose $C$ in plaice}

The inclusion of glucose and dextrin in the food given to plaice did not markedly affect the blood glucose level. Blood glucose concentration in fish given diet I (free of carbohydrate) was $1.77 \pm 0.1 \mathrm{Imol} / 1$ and that in fish given diet 9 (200 g carbohydrate $/ \mathrm{kg}$ ) was $2 \cdot 1 \mathrm{I} \pm 0.23 \mathrm{mmol} / \mathrm{l}$. These values are not significantly different. The glucose levels in wild plaice are reported to be $0.83^{-1} \cdot 39 \mathrm{mmol} / 1$ (Wardle, 1972).

The presence of carbohydrate in the diet did lead to an increase in the liver glycogen level. Plaice given diet 9 had liver glycogen levels of $56 \cdot 64 \pm 6 \cdot 48 \mathrm{mg} / \mathrm{g}$ fresh liver, significantly more $(P<0.01)$ than fish given diet $\mathrm{I}(25.47 \pm 3.68 \mathrm{mg} / \mathrm{g}$ fresh liver). Histological examination of the livers of fish given diet 9 did not reveal any detectable pathology and it did not appear that the liver glycogen levels found were in any way deleterious.

The results of the experiments designed to examine the metabolic fate of glucose $\mathrm{C}$ atoms in fish are summarized in Table 6 . The fraction named 'residual ${ }^{14} \mathrm{C}$ ' includes radioactivity present in nucleic acids, 'tissue-bound' lipids and any ${ }^{14} \mathrm{C}$ lost during the purification of the protein and of the glycogen fractions (Vrba, 1966).

The main contrast between our results with plaice and those of Vrba using mice lies in the rate at which intraperitoneally injected glucose is either directly or indirectly respired; $18 \mathrm{~h}$ after the injection of the radioactive glucose into plaice up to about $23 \%$ (depending on dietary treatment) had been expired as $\mathrm{CO}_{2}$. By contrast expiration of glucose $\mathrm{C}$ by the mouse was some 10- to 20 -fold more rapid, thus over $30 \%$ of injected glucose $\mathrm{C}$ had been expired by the mouse only $\mathrm{I} h$ after injection; $8 \mathrm{~h}$ after the intraperitoneal injection of $\left[\mathrm{U}^{14} \mathrm{C}\right]$ glucose, $82.5 \%$ has been expired as ${ }^{14} \mathrm{CO}_{2}(\mathrm{Vrba}, \mathrm{1966})$. Substantially similar results were obtained by Bloom, Stetten \& Stetten (1953) using rats.

A further point which is not evident from Table 6 is that the radioactivity (from glucose or acid-soluble compounds derived from glucose) present in the acid-soluble fraction in the mouse decreases rapidly. Only about $3 \%$ of it remains $8 \mathrm{~h}$ after the injection of radioactive glucose (Vrba, 1966). By contrast, over $50 \%$ of the injected radioactivity was still present in plaice in the acid-soluble fraction $18 \mathrm{~h}$ after injection of $\left[\mathrm{U}-{ }^{14} \mathrm{C}\right]$ glucose. The magnitude of the difference here is about $3^{\circ}$-fold. 


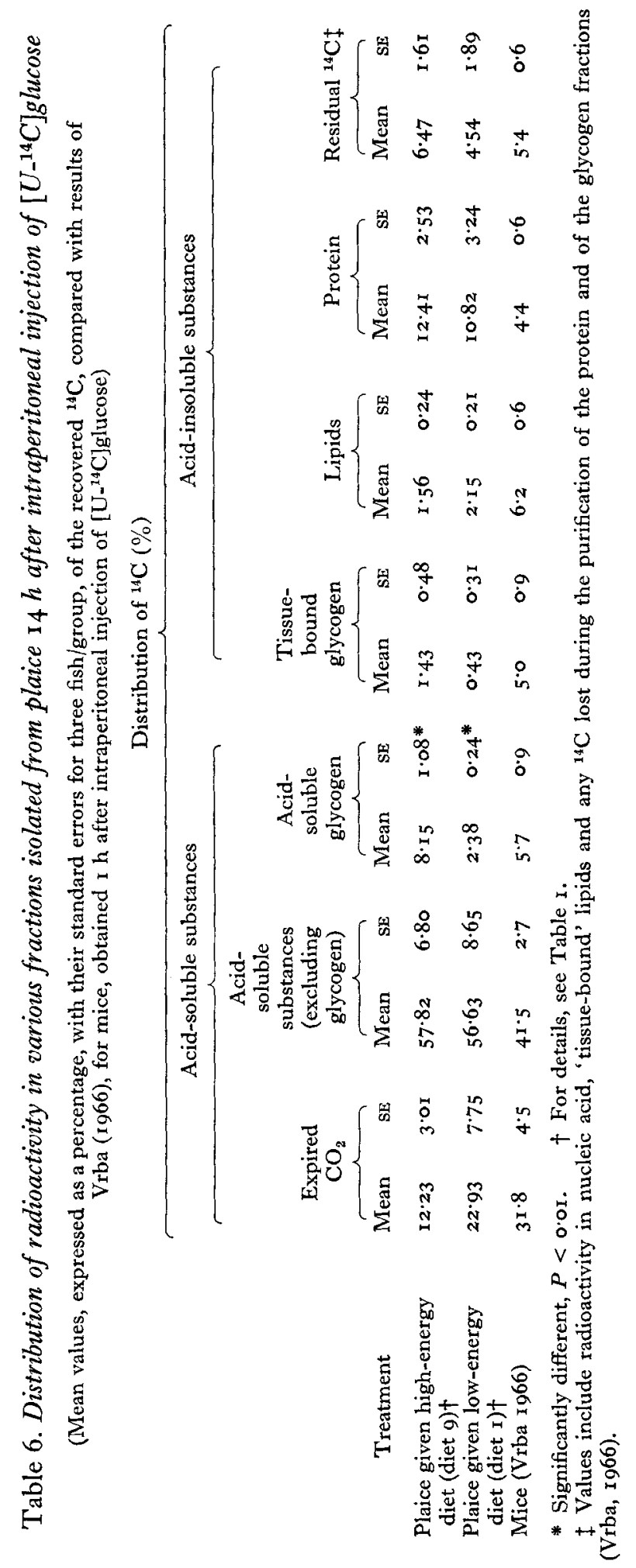


No other marked differences between plaice and mouse in the fate of glucose $\mathrm{C}$ atoms were evident (see Table 6), although the indications were that rather more glucose $\mathrm{C}$ is converted to lipid in the mouse than in plaice.

The metabolism of glucose by plaice was affected in some ways by the composition and energy content of the diet. When they were given a high-energy diet containing assimilable carbohydrate (diet 9) more glucose was incorporated into glycogen than with diet I. It also remains possible that a real difference exists between the two treatments in the amount of glucose respired by fish given these dietary treatments. This difference may be obscured in the present results by the small number of observations taken, together with the inherent variability of the fish.

The differences noted above, between the cold-blooded plaice and the warmblooded mouse, in the rate at which glucose is respired may be partly due to the different temperatures at which the animals live. The plaice were held at $15^{\circ}$ while mouse tissues function nearer $40^{\circ}$. However, this is unlikely to be the sole or main factor which is operative because, assuming a 2 -fold increase in reaction rate for every $10^{\circ}$ increase in temperature, the expected difference in rate of glucose oxidation between the two animals would be, on this basis, about 5 -fold. In fact, as previously stated, the difference was nearer 20 -fold. No systematic attempt was made to examine metabolic factors affecting glucose metabolism in plaice, but as phosphorylation of glucose is generally regarded as the first rate-determining stage in its catabolism by liver, measurements of hepatic hexokinase in plaice were made. In fish given diet 9 , hexokinase activity was $0.184 \pm 0.082 \mu \mathrm{mol}$ glucose phosphorylated/g liver per min; the corresponding value for fish given diet I was $0.129 \pm 0.03 \mathrm{I}$. There was no significant difference between these values. Assays of plaice liver hexokinase activity in the presence of high glucose concentrations $(50 \mathrm{~mm})$ did not lead to any increase in activity indicating the absence of a high- $K_{m}$ enzyme (glucokinase). There was no evidence that such an enzyme was induced by administering the levels of carbohydrate used in diet 9 .

\section{DISCUSSION}

The results of the experiments reported here are in broad agreement with those of Lee \& Putman (1973) using rainbow trout, in that a sparing action of lipid and of carbohydrate on protein utilization occurred in plaice given high-protein rations. The sparing action of lipid on dietary protein was only achieved, however, at the expense of an increasingly fatty carcass.

A feature of the results was the effect on both weight gain and protein retention obtained when assimilable carbohydrate was included in the diet as compared with diets of similar energy content lacking carbohydrate. Buhler \& Halver (196r) earlier observed a similar effect in experiments with Chinook salmon; replacement of dietary carbohydrate (dextrin) by lipid led to a decrease in weight gain and food conversion by the fish. Buhler \& Halver (196I) compared this effect with that observed by Thomson \& Munro (1955) using rats, namely that when fat was exchanged isoenergetically for carbohydrate in the diet of the rat, urinary $\mathrm{N}$ output increased for a few days and then returned to its former level. The effect was short-lived and was shown later 
(Munro, Black \& Thomson, 1959) to be due to enhanced incorporation of amino acids into muscle protein. By contrast the effects observed by Buhler \& Halver (1961) were long-lasting (an experiment of 14 weeks' duration).

The more recent experiments of Hartsook, Hershberger \& Nee (1973) may be apposite to the present discussion. Their results indicate that the carbohydrate:fat ratio affects $\mathrm{N}$ retention in rats at high protein intake. The absolute gain of $\mathrm{N}$ by the rat was independent of fat: carbohydrate ratio in diets containing $440 \mathrm{~g}$ protein $/ \mathrm{kg}$. Below this value high fat: carbohydrate ratios led to higher efficiency of $\mathrm{N}$ gain and above this value to lower efficiency of $\mathrm{N}$ gain. Thus it seems that in the omnivorous mammal as well as the carnivorous fish the presence of carbohydrate as an energy source may, under particular conditions, have beneficial effects.

A point which should be emphasized when considering the present results is that half the carbohydrate, in those diets which contained this material, was present as glucose. Smith (1971) observed that more positive $\mathrm{N}$ balances were obtained, in experiments on rainbow trout, when diets contained simple carbohydrates than when they contained raw starch. Thus the effects obtained in experiments with fish may be dependent on the complexity of the carbohydrate provided.

No results are available for carbohydrase activity in the digestive tract of plaice but in another marine fish, namely cod (Gadus morhua), amylase activity in the digestive tract was low (Overnell, 1973).

The levels of assimilable carbohydrates used in the present experiments were low compared with those normally present in mammalian rations. No histopathology associated with the use of these dietary carbohydrate levels was observed. However, carnivorous fish apparently lack the endocrine mechanism necessary to cope with sudden heavy loads of glucose as, for example, when they are subjected to glucose tolerance tests (Palmer \& Ryman, 1972). Moreover the relative rates at which glucose is oxidized by plaice and by mammals (Table 6) suggests that glucose is less important as a substrate for oxidation in the plaice than in the mammal. This state probably arises from long-term adaptation of the fish to diets low in carbohydrate.

The lack of an inducible glucokinase in plaice seems to be another aspect of this adaptation. The $K_{m}$ value of mammalian glucokinase is of the order of $5_{5}^{-20} \mathrm{mM}$, consequently glucose phosphorylating activity increases when blood glucose levels rise from the fasting level $(4-5 \mathrm{mmol} / \mathrm{l})$ toward the renal threshold level, Io $\mathrm{mmol} / \mathrm{l}$ (Walker, 1966). In the present experiments the plaice glucose levels were of the order of $2-3 \mathrm{mmol} / \mathrm{l}$ and clearly a high- $K_{m}$ glucose kinase would function very inefficiently, if at all, under these conditions.

Finally, in this context, it is worth remarking that similar considerations apply to the glucose dehydrogenase present in trout liver (Shatton, Halver \& Weinhouse, I971) and more recently shown to occur in the livers of several other fish, including marine species (Nagayama, Ohshima \& Takeuchi, 1973). The activity of this enzyme is 10-100 times greater in trout than in rat liver (Shatton et al. 1971). However, at physiological $\mathrm{pH}$ the $K_{m}$ (glucose) of the trout enzyme is $40 \mathrm{~mm}$ with $\mathrm{NAD}^{+}$as coenzyme (Shatton et al. 1971) and it is therefore difficult to see how the enzyme functions as a glucose dehydrogenase under physiological conditions. The question is 
compounded by the fact that the $K_{m}$ of the enzyme for glucose-6-phosphate is $0.01 \mathrm{mM}$ so that the physiological role of the enzyme appears to require further elucidation.

We are grateful to Dr P. T. Grant for his continued interest in this work and his critical comments during its course.

\section{REFERENCES}

Bloom, B., Stetten, M. R. \& Stetten, D. (1953). F. biol. Chem. 204, 68r.

Braber, L. \& De Groot, L. J. (1973). Neth. Э. Sea Res. 6, I63.

Buhler, D. R. \& Halver, J. E. (196r). 7. Nutr. 74, 307.

Cowey, C. B., Adron, J., Blair, A. \& Shanks, A. M. (r 974). Br. Y. Nutr. 31, 247.

Cowey, C. B., Pope, J. A., Adron, J. W. \& Blair, A. (1972). Br. F. Nutr. 28, 447.

Cowey, C. B. \& Sargent, J. R. (1972). Adv. mar. Biol. 10, 383.

Dupree, H. K. (1969). Tech. Pap. Bur. Sport Fish Wildl. U.S. no. 27.

Edwards, R. R. C., Finlayson, D. M. \& Steele, J. H. (I969). F. exp. mar. Biol. Ecol. 3, x.

Hartsook, E. W., Hershberger, T. V. \& Nee, J. C. M. (1973). F. Nutr. 103, 167.

Krebs, H. A., Bennett, D. A. H., De Gasquet, P., Gascoyne, T. \& Yoshida, T. (I963). Biochem. $\mathcal{F}$. $86,22$.

Lee, D. J. \& Putnam, G. B. (1973). F. Nutr. 103, 916.

Lee, E. Y. C. \& Whelan, W. J. (1966). Archs Biochem. Biophys. I16, 162.

Munro, H. N., Black, J. G. \& Thomson, W. S. T. (г959). Br. F. Nutr. r3, 475.

Nagayama, F., Ohshima, H. \& Takeuchi, T. (1973). Bull. Fap. Soc. scient. Fish. 39, 1349.

Overnell, J. (1973). Comp. Biochem. Physiol. 46, 5 I9.

Palmer, T. N. \& Ryman, B. E. (1972). F. Fish Biol. 4, 31 I.

Phillips, A. M. (1969). In Fish Physiology Vol. I, p. 391 [W. S. Hoar and D. J. Randall, editors]. New York: Academic Press.

Shatton, J. B., Halver, J. E. \& Weinhouse, S. (197I). f. biol. Chem. 246, 4878 .

Smith, R. R. (1971). Progve Fish Cult. 33, r32.

Swanson, P. (1959). In Protein and Amino Acid Nutrition p. r95 [A. A. Albanese, editor]. New York: Academic Press.

Thomson, W. S. T. \& Munro, H. N. (1955). F. Nutr. 56, 139.

Vrba, R. (1966). Biochem. F. 99, 367 .

Walker, D. G. (1966). In Essays in Biochemistry Vol. 2, p. 33 [P. N. Campbell and F. Dickens, editors]. London: Academic Press.

Wardle, C. S. (1972). F. mar. biol. Ass. U.K. 52, 635 . 